\title{
FROM CRAFT TO INSTITUTION: INSTITUTIONAL ANALYSIS AND THE MEDIEVAL ACCOUNTING HISTORY
}

\author{
Olga Volkova \\ National Research University, Saint Petersburg, Russia
}

\begin{abstract}
This paper investigates if accounting evolved as a result of the interaction of special economic, cultural and political institutions which prevailed in Medieval Italy. A two stepapproach is implemented by the Historical and Comparative Institutional Analysis. First we investigate the features of above institutions led to accounting institutionalization. We found business environment, political, social, economic and cultural factors which was significant to this process. Second we showed the institutionalization of accounting to be completed to the XIV century, when it became a system of codified technical standards, scholar discipline and professional field.
\end{abstract}

Keywords: accounting, social institute, economic history, accounting history

JEL: B11, B15, B52, D02, M41

\section{Introduction}

The last two decades, with the emergence and development of new methods in historical, social, and economic sciences, interest grows to the accounting in general and accounting schools' history. Besides, a new wave of institutional research rose the interest to the mutual influence of the accounting and other socio-economic institutions (see, e.g., Parker, 1997; Zan, 2005; Thornton et al., 2005; Gomes et al., 2011). This interest is caused, first of all, by the role accounting plays in the modern financial world and increasing needs for the financial and business information.

It cannot be underestimated the general trends in social and humanity sciences, the philosophical foundations of the history, politics, law. Significant breakthroughs had done at the intersection of these disciplines and the economy in the new millennium.

The purpose of this paper is to trace the emergence and evolution of accounting (knowledge and practice) in Italy XII-XVI centuries in its institutional aspect, in interrelation with progress of cultural, business and social environment of that time. We are about to check whether cultural revolutions caused accounting transformation from craft to social institution. The main results are (1) to show that the emergence of social and economic institutions of accounting occurred as a result of interaction of objective and subjective factors (of political, social, economic and cultural nature); (2) to allocate the stages of institutionalization process; (3) to prove that the visual aspects of culture and innovative technologies were the crucial for accounting revolutions since the second millennium beginning.

Sources of information about the accounting practices of medieval Italy are both archival and analytical. Extant written sources of the Italian accounting information saved to our days are dated by middle ages or early Renaissance (Bryer, 1993, p. 116; Lee, 1973, p. 137; Rutenburg, 1965, 1987, pp. 161-163; Gurskaya, 2010, pp. 50-53). Mostly they relate to trade transactions carried out in Genoa, Florence, Milan, Venice. Accounting practice in northern Italy was conducted by private companies and also cities' administration bodies.

The interdisciplinary nature of the research causes the methodology used. The analysis of the accounting institution evolution needed synthesis of social, historical and economic sciences methods. The institutional, structure-functional and typological analysis, the historical 
research methods are used. The core method of this research is the Historical and Comparative Institutional Analysis (Greif, 2006).

\section{Factors of accounting institutionalization}

To answer when and how institutionalization started, we are to consider three aspects of Italian society of the late Middle Ages and our knowledge about it.

Economic context of the Italian merchant (commercial) capitalism, considered by many researchers since the 1850 's. The view dominates that commercial revolution originated from the northern Italy near the tenth century (Lopez, 1976, p. 126) was both a social revolution. It means that the land ownership and the administrative seals in the cities were transformed into a commercial capital and commercial power.

From the antiquity, the individual or family assets were invested in a personal or family business. From the beginning of the second millennium joint capital began to develop. Mutual assets started to be invested in various, independent of each other, companies or projects (merchant expedition, royal loans, etc.), allowing their owners to get a return on investment. The assets in the financial pools lost their individuality.

This transition from the personal management of individual resources, typical for Roman imperial period, to the management of the investors' group capital, in the interests of all its members, meant the process of socialization of capital. New economic institutions of socialized capital required new technologies of information exchange which could support the reciprocity and assurance institutes. Accounting became such technology. So, the emergence of accounting techniques was the result of commercial capitalism in the Northern Italian cities.

The effect of socialization was strengthened by the production specialization of city communes and the favorable context for overseas trade in the coastal cities, especially Venice and Genoa. The return on investments became a criterion of management efficiency for the independent investors. Accounting, and especially double-entry records, giving tools for decision-making on distribution of the capital and management efficiency control to them, represented spirit of capitalism (see, for example, Yamey, 1964, p. 117; Zombart, 2010 [1913], pp. 171-172).

Cultural context. The issues of the cultural contexts of accounting origin and evolution (in particular the double-entry) was initially raised by Littleton in his fundamental work on the history of accounting (Littleton, 1933) where he stated influence of writing, arithmetic, monetary systems, property rights, and the Crusades on these processes. In much more details, the general cultural context was examined later (see, e.g., Hoskin, Macve, 1986; Thornton et al., 2005).

We assume the factors allocated in mentioned-above works to be divided into two groups linking with representational and communicational technologies.

Representational factors define how new technologies were introduced into the practice. They have been associated with the following changes in the beginning of the second millennium:

- getting ground of Arabic decimal numbering in Europe, which was much more convenient for financial calculations and control than the Roman numbering;

- spreading of the visual forms of information - the separation of words and sentences, structuring text into parts and paragraphs, tabs, arrangement and systematization of information in alphabetical order, the emergence of cross-references and derivative 
documents (for example, accounting journals or comments for texts) - as opposed to audible forms of representation prevailed in antiquity and the early Middle Ages;

- usage of the vernacular (national language) in the writings for local purposes and in texts for distribution (in books and scientific treatises).

All these changes were not Italian only. Similar processes in XII-XV centuries took place in England, France and other European countries. Nevertheless, Italy was the first in these innovations.

Communicational factors - education and replication of books (including study books) allowed to expand and to simplify information distribution. These factors, on the contrary to representational ones, evolved in Italy earlier than in other European countries.

In contrast to the economic, communicational aspects of medieval society, the influence of cultural technologies on the nascence and the interaction of economic and social institutions had been raised only in the last quarter of century. The pioneer paper was (Hoskin, Macve, 1986) where they analyzed the influence of accounting to various areas of human activity in keeping with the philosophy of Michel Foucault. In our work, we think it is important to focus on the contrary - the impact of cultural institutions and technologies, first of all - education, on the uprising of the technologies and institutions of accounting.

Business in XII-XV centuries was maintained with ongoing control and estimation procedures for assets, liabilities and operations, financial results and the participants' shares. Monitoring and evaluation of the technologies implemented in the education system at all levels prepared students for the use of these technologies in their future practices. It was consistent with the requirements of social capital.

The development of education of all forms and levels - from primary to university - was one of the most important factors in the development and institutionalizing of accounting in Italy in the first half of the second millennium. As we assume, the secondary and professional education in the Italian cities of that period ensured the wide spread of the registration technologies, while the influence of the university education to the economic practices in the first centuries of accounting institutionalization affected, mainly, by spreading the ideas of estimation and current control.

Political context. The influence of political factors on the institutionalization of accounting had less attention in the literature. However, the political structure of northern Italy during the reviewed period was very specific, and as we assume, it can also be considered as one of the prerequisites for the accounting institutionalization. Two features defined Northern Italian political scope of that time: communal power at first, and the professional guilds, at second.

The Northern Italy, in contrast to most other regions of Europe, up to the middle of XIX century did not occur in any monarch state. Personal freedom and the absence of royal financial duties formed business opportunities, unprecedented for the rest of Europe of the first third of second millennium. This was followed by the formation of social capital.

The structure of civil society in the cities of northern Italy in the Middle Ages plays important role in the socialization of capital, and as a consequence - the institutionalization of accounting. Back in the VIII-IX centuries, the ancient Roman settlements of the territory was formed primarily as the centers of trade and handicrafts - Milan, Venice, Genoa, Bologna, Pisa, Luca, a little later - Florence, Padua, Siena. In the XI-XII centuries the city communes established with the elected leaders and authorities. By the end of that period, communes formed in dozens of cities in northern and central Italy, and up to the XIII century - and in rural areas. Largely due to economic independence and republican governments, the communes became the centers of production and commodity-money exchange, and then, in 
the XIII century - the financial transactions too. Prevailed in the business environment of Northern communities, commercialism and the fact that their residents were not citizens of any sovereign simplified the economic expansion of capital to other countries. So, temporal and spatially distributed business transactions presented demand for credibility institutions including accounting.

In conducting both domestic and foreign transactions merchants and bankers - the citizens of the communes - influenced and controlled by professional guilds. The guild was the form of professional bodies and arose in the cities initially in XI-XII centuries. They took an active part in the municipal government. In this regard, we think it is important to highlight the role of guilds as institutions of control and assurance of "rules of the game" in the operating activities (production and trade with external parties), the interactions with the government (tax payment) and the relationships within the community.

Being the form of professional associations, guilds were in fact not only the elements of civil society, but also a part of the political system and public administration. Guild established the rules and technology to enforce them, which, in turn, entailed the need to use accounting techniques for the members of these communities.

So, we assume that the institutionalization of accounting in medieval Italy was defined by the set of above-mentioned economic, cultural and political factors and features. Most authors pay attention to economic context of accounting progress. In contrary, we guess cultural factors to be decisive. The institute is influenced not only by economic factors, but also social - religion, the system of family ties, trust among members of society. With very similar peculiarities of doing business and trade financing activities information support operations may be different, and even if the registration account of the facts of economic life can not develop the institute (Greif, 2006).

\section{Components of accounting institutionalization: practice, knowledge, profession}

The considered factors created favorable environment for institutionalization of accounting practice. The evolution of accounting-related activity in Italy traces the features common to most processes of institutionalization on the initial phases.

The first one was the emergence of a need which required some organized action. In our case, the entrepreneurs had a need to record and store information on deals. Next stage was the generation of common goals for a group of persons that was ensuring for the financial efficiency (profitability, expansion of the markets, etc.) of commercial operations carried out by groups of independent investors. The results of that operations (profits or losses) were the subject for the economically reasonable distribution between participants. These two stages of an institutionalization of the accounting begun together with commercial revolution in $\mathrm{X}$ century and was completed by the XII century as an accounting craft (techniques) institutionalization.

In accordance with the general principles of institutionalization, after realizing the need for the emergence of some institutions, rules, regulations and procedures should be issued. This occurs gradually by trial and error. The next stage: publication of written recommendations describing the best practice - treatises and books. This began at the turn of the XII-XIII centuries and was particularly widespread in the next two centuries when accounting became a system of codified technical standards, scholar discipline and professional field, t.e. the socio-economical institution.

By the beginning of the XIV century commercial education and the need for business practices regimentation have led to the creation of study books which introduced financial 
transactions and accounting technologies to pupils. The Florentine children studied by Giovanni da Uzzano treatise "The book on the trade and customs of other countries" (Villani, XIV c.; Rolova, 1994) and the textbook "The Practice of trade" ("Prastica della mercatura») by Francesco di Pegolotti. These books contained information how to conduct trading records. Published century later, Luca Pacioli's "Summa de arithmetica, geometria, proportioni et proportionalità" became most known but not the first book on accounting. Pacioli's predecessors Benedetto Cotrugli (Yamey, 1994) and the author of "La Riegola de Libro" (Postma, van der Helm, 2000) open new era in accounting institution evolution, they started proto-scientific period of accounting knowledge institutionalization.

The emergence of statuses and roles system for all involved in accounting practice can be considered as the beginning of accounting profession institutionalization. In our case, it was the assignment of trade associations' members who was responsible for the maintenance of accounting records. In the beginning of commercial revolution such persons were, generally, financial partners, performing its functions "on the site". Later, with the emerging of professional clerks and supervisors (auditors) this activity has been separated from the actual commercial.

First requirement for candidates to engage in accounting activity were recorded for the members of the Board of government auditors of the Venetian Republic. To take this position, it was necessary to have not only the respectful origins but also extensive experience in financial matters, as well as a special examination (Zambon, 1998).

First universities in Western Europe contributed to the institutionalization of accounting profession too, because they offered to their scholars the administrative disciplines and law courses in addition to the traditional for that time scholastic and theology. The Universities was institution of knowledge accumulation and transmission, so the prestige of degree contributed to the maintenance of a high status of all activities that are engaged in master's degrees. After passing through the filters of all university examinations, they found themselves in business, government and church government, creating a new type of professional managers.

So, up to the mid of millennium the institutialization of accounting was completed (Volkova, 2012).

\section{Summary}

In Northern Italy from the XII to the XV century a transition occurred from the intuitive use of the individual recordkeeping of the economic life facts to the standard rules (institutionalization of practices); techniques were published and became available for study and use (the institutionalization of knowledge); professional accounting society was formed from the sideline practices concomitant another (trade, exchange, credit) activity to the highly specialized activity (institutionalization of the profession).

As was shown in this article, accounting in medieval Italy by the 12th century began to acquire features of social and economic institute. Three groups of prerequisites determined this process: (1) the special organization of trade business and property on the financial assets which developed in northern Italy by the end of the period of the Middle Ages and led to forming of a social capital; (2) emergence and development of new methods of visualization, the representation and transfer of information that gave a material basis for creation of calculating technologies of information support of various areas of human activities from education before public administration, including technologies of accounting of economic 
transactions; (3) personal liberty of citizens of the North Italian cities in case of implementation of business activities, including transcontinental.

\section{References}

Bryer, R. (1993). Double-Entry Bookkeeping and the Birth of Capitalism: Accounting for the Commercial Revolution in Medieval Northern Italy. Critical perspectives on Accounting, no. 4, pp. 113-140.

Gomes, D., Carnegie, G., Napier, C., Parker, L., West, B. (2011). Does accounting history matter? Accounting History, vol. 16, no. 4, pp. 389-402.

Greif, A. Institutions and the Path to the Modern Economy: Lessons from Medieval Trade. Cambridge: Cambridge University Press, 2006.

Gurskaya, M. (2010). That we knew about the Florentine company of Peruzzi and that it is possible to tell the new. Uchet i statistika, no. 4, pp. 49-53. (In Russian).

Hoskin, K., Macve, R. (1986). Accounting and the examination: A genealogy of disciplinary power. Accounting, Organizations and Society, 11 (2), pp. 105-136.

Lee, G. (1973). The Development of Italian Bookkeeping 1211-1300. Abacus, vol. 9, no. 2, pp. $137-155$.

Littleton, A. (1933). Accounting Evolution to 1900. New York: Russel \& Russel.

Lopez, R. (1976). The Commercial Revolution on the Middle Ages: 950-1350. Cambridge: Cambridge University Press.

Parker, L. (1997). Informing Historical Research in Accounting and Management: Tradition, Philosophies and Opportunities. Accounting Historians Journal, vol. 24, no. 2, pp.111-49.

Postma, J., van der Helm, A. (2000). La Riegola de Libro. Bookkeeping instructions from the mid-fifteenth century. The 8th World Congress of Accounting Historians. (Electronic Resource: home.kpn.nl/annejvanderhelm/paper.html)

Rolova A. (1994). Italian Merchant and his Trading and Bank Activity in the XIII-XV centuries. Srednie veka, vol. 57. pp. 62-74. (In Russian)

Rutenburg V. (ed.) (1965). Merchant Books of Uzzano's Company, 1363-1386. In Italian Communes XIV-XV century. Moscow. (in Russian).

Rutenburg V. (1987). The Italian city from the early Middle Ages to the Renaissance. Moscow: Nauka. (in Russian).

Sombart, W. (2010 [1913]). Der Bourgeois: zur Geistesgeschichte der modernen Wirtschaftsmenschen. Charlston: Nabu Press.

Thornton, P., Jones, C., Kury, K. (2005). Institutional Logics and Institutional Change in Organizations: Transformation in Accounting, Architecture, and Publishing. Research in the Sociology of Organizations, vol. 23, pp.125-170.

Villani, G. (XIV c.) Nuova Cronica. http://www.letteraturaitaliana.net/pdf/Volume_2/t48.pdf

Volkova, O. N. (2012). From Craft to Institution: accounting in Italy from the Middle Ages to the Renaissance // Voprosy Economiki, no. 11, pp. 135-152. (in Russian)

Yamey, B. (1964). Accounting and the Rise of Capitalism: Further Notes on a Theme by Sombart. Journal of Accounting Research, vol. 2, no. 2, pp. 117-136. 
Yamey, B. (1994). Benedikt Kotruljević on bookkeeping (1458). Accounting, Business \& Financial History, vol. 4, no 1. pp. 43-50.

Zambon, S. (1998). Italy / Alexander, D. and Archer, S. (eds.). The European Accounting Guide, 3rd ed. New York: Academic Press, Hartcourt Brace Jovanovich.

Zan, L. (2005). Future Directions from the Past: Management and Accounting Discourse in Historical Perspective. In Advances in Strategic Management, vol. 22, pp. 457-489. 